\title{
路面のラフネスに対する 車両乗員の生理心理反応と許容限界評価
}

\author{
富山和也 ${ }^{1} \cdot$ 川村 彰 $^{2} \cdot$ Riccardo Rossi $^{3} \cdot$ Massimiliano Gastaldi $^{4} \cdot$ Claudio Mulatti $^{5}$ \\ 1 正会員 博士（工） 北見工業大学 工学部 （ $\bar{T} 090-8507$ 北海道北見市公園町 165） \\ E-mail : tomiyama@mail.kitami-it.ac.jp \\ 2 正会員 博士（工） 北見工業大学 工学部 （广090-8507 北海道北見市公園町 165） \\ ${ }^{3}$ Non-member, Ph.D., Dept. of Civil, Architectural and Environmental Eng., University of Padova \\ (Via Marzolo, 935131 Padova, Italy) \\ ${ }^{4}$ Non-member, Ph.D., Dept. of Civil, Architectural and Environmental Eng., University of Padova \\ (Via Marzolo, 935131 Padova, Italy) \\ ${ }^{5}$ Non-member, Ph.D., Dept. of Developmental Psychology, University of Padova \\ (Via Marzolo, 835131 Padova, Italy)
}

\begin{abstract}
本研究は, 車両乗員の安全性および快適性の観点から, 路面のラフネスとヒトの精神的ストレスおよび認知 に関わる生理心理応答との関係について，ドライビングシミュレータを用いた走行試験を実施し検討したもの である. 結果として, 国際ラフネス指数 (IRI) の増加に伴い, 心理応答である反応時間が有意に増加する場合, 生理的な心拍変動指標により定量化された短期および長期的な精神的ストレスが共に増加することがわかった. この結果より，ラフネスの増加は，快適性の低下のみならず，疲労の増加に伴う反応時間の増加により，安全 性の低下につながることを明らかにした．また，ヒトの生理心理反応に基づき，幹線道路におけるIRI の許容限 界について検討したところ, $5.4 \mathrm{~mm} / \mathrm{m}$ となり, 既存の研究成果を裏付ける結果が得られた.
\end{abstract}

Key Words : surface roughness, reaction time, heart rate variability, physiopsychology, driving simulator

\section{1.はじめに}

道路と車両の接点となる路面の状態は，利用者評価に 直結することから，質的満足度の高い社会基盤整備を行 う上で久か寸ことのできない要因である. そのため, 路面 の定期点検結果に基づく定量的な性能評価は，限られた 投資予算で効果的に道路ストックを運用していく上で必 要不可欠である. さらに, 国内外において車両の自動走行 実現へ向けた研究開発が盛んに行われている今日，豊か なモビリティ社会を実現し維持していくためには，快適 性および安全性に関わる路面性能の確保は，さらに重要 さを増すものと考えられる. 特に, 路面のラフネスは, 快 適な交通を確保する上で必須の性能指標であり ${ }^{1}$, 舗装の サービス性能に直結寸ることから ${ }^{22}$ ，その合理的な評価は，
道路利用者に対し質の高い道路交通サービスを提供する 上で極めて重要な役割を果たす。

従来から, ラフネスは, 走行車両の振動要因となり, 乗 員に直接影響を及ぼすことから, その評価には, 路面とヒ 卜および車両の特性に関する以下の指標を用いた検討が なされている.

(1) 物理指標 : ラフネスを直接評価するための指標とし て，国際ラフネス指数（International Roughness Index:

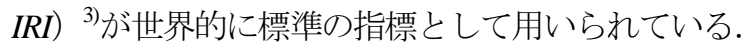
ISO では，パワースペクトル密度 (Power Spectral Density: PSD） により路面プロファイルの振幅を評価 する方法 ${ }^{4}$ を規定している. また, 路面を走行する車 両の振動加速度に基づき, 乗員の全身振動曝露量を 定量化し,ラフネスと関連付ける方法 ${ }^{5)}$ が提案されて 
いる.

（2）心理指標: 道路利用者を対象に走行試験を実施し, 特 に乗り心地に立脚した車両乗員の体感に基づくアン ケート評価值とラフネスを関連づける研究が古くか ら行われている ${ }^{0,7) . ~}$

(3) 生理指標: 生体センシング技術の発達により, 車両乗 員の心拍数 ${ }^{8}$ や脳波 ${ }^{9}$ 計測に基づく生理指標とラフネ スを関連づける研究がなされている.

このように，ラフネス評価に関わる要素は非常に多岐 にわたり，例えば，ISOでは，全身振動曝露に関する評価 方法 ISO2631-1 (1985) ${ }^{10)}$ で示されていた曝露限界が，同 $(1997)^{11)}$ の改訂版では取り下げられ，乗り物の振動につい ては不快感と対応したおおよその加速度範囲を付録とし て示寸に留まっており, 人の快適性評価の複雑さが窺え る. また, 従来のラフネスに関する研究は, 振動乗り心地 に立脚したものが主であり，安全性と快適性に基づきラ フネスと利用者評価を関連づける上で，ヒトの情報に基 づく定量的な検討は未だ不十分であると考えられる.

本研究の目的は, 路面条件を考慮した走行試験により, 上述の物理・心理・生理的視点を統合し, ラフネスに対す るヒトの生理心理反応および許容限界について明らかに することである. そこで, 本研究では, 車両乗員の安全性 および快適性の観点から, ラフネス指標であるIRI と, ヒ

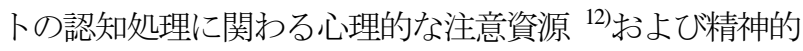
ストレスに関わる生理的な自律神経系の活動 ${ }^{13)}$ との関係 に基づく検討を行う。

なお，本研究における走行試験は，試験参加者（以下， 「参加者」）の安全性に配慮し，かつ必要とする路面条件 を効率的に確保するため，予めラフネス評価への適応性 が検証された，路面評価型のドライビングシミュレータ

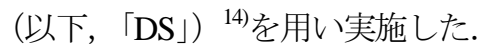

\section{2. 物理・心理 $\cdot$ 生理指標の概要}

本研究では, 物理・心理・生理的な要因を考慮したラフ ネス評価にあたり, 既往研究 ${ }^{3,55-9)}$ を参考に, 各要因につ いて以下の代表的な指標を用いる.

\section{(1) 物理指標}

物理指標は, ラフネスの評価指標として世界的に標準 となっており, 国内でも, 近年策定された舗装点検要領 ${ }^{15}$ において必須の点検項目となっているIRIを用いる.

\section{（2）心理指標}

複数の作業や情報の認知的処理に対し, 同時に向けら れる注意は分割されて配分される. その処理に必要な心 的エネルギーが注意資源であり，その量には限界がある
ことが知られている ${ }^{12)}$ ，例えば，複数与えられた刺激の 一つに注意を向けた場合，異なる刺激での注意資源量が 低下し, 要求課題へのパフォーマンスが低下寸る.この注 意資源が影響する認知過程の把握には，与えられた刺激 に対する反応時間（Reaction Time）を指標とした行動的方 法により評価することができる. そのため, 反応時間は, 道路交通環境下での運転行動評価への適用事例が報告さ れている ${ }^{16-18)}$. 本研究では, ラフネスがヒトの認知処理に 及ぼす影響を把握するため, 反応時間を心理反応の指標 として用いる.

\section{（3）生理指標}

ヒトの生理反応は, 生体センシング技術の発達により, 簡便かつ非拘束・非侵襲での計測が可能となっている. 精 神的ストレスの評価には, 心拍変動の周波数領域におけ る自律神経系指標の有効性が確認されている ${ }^{13)}$. 心拍変 動とは, 心拍数の摇らぎであり, 精神的ストレスなどによ って変化する自律神経系の活動を表す重要な生体情報の 一つである. 特に, 既往研究 ${ }^{19}$ では, 心拍変動解析によ り, 路面由来の車両振動に起因する潜在的な精神的ス卜 レスの把握が可能であることを明らかにしている．そこ で, 本研究では, 精神的ストレスに関わる生理的な反応と して心拍変動に着目寸る. 特に, 心拍変動は, 周波数領域 における高周波成分 (HF: 0.15-0.4Hz) と低周波成分 (LF： 0.04-0.15Hz) から, 副交感神経系および交感神経系のスト レス指標として高周波成分 $\mathrm{HF}$ および低周波高周波成分 比 LF/HF を用いる．ここで，副交感神経系を表す HF は 安静状態, 即ちストレスのない状況下で増加し, 交感神経 系を表す LF/HF はストレス状況下で増加する性質がある。

\section{DSによる走行試験}

\section{(1) DS の概要}

DS を用いた走行試験は，実道試験に比へ，安全性の確 保や実験条件の容易な設定，同一条件で繰り返し試験が 行えるなど多くの利点を有する. 本研究では, ラフネスに 起因する車両振動以外の環境変動要因を排除し, 試験条 件を単純化するため, 路面性状に関する実データの利用 および再現が可能な, 北見工業大学所有の路面評価型 DS を用いて走行試験を実施した. 路面評価型DS は, ラフネ スと関連する数センチメートル単位の路面波長まで再現 することが可能である. また, 路面評価型 DS による仮想 環境下での走行試験結果は, 実道試験と同様の傾向が得 られることを確認している ${ }^{14)}$.

\section{（2）試験シナリオ}

走行試験における路面条件は, 一般道路の新設, 供用中 


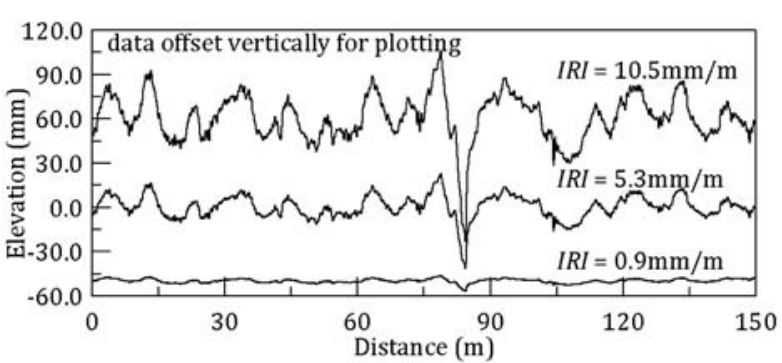

図-1＼cjkstart走行試験における路面プロファイル

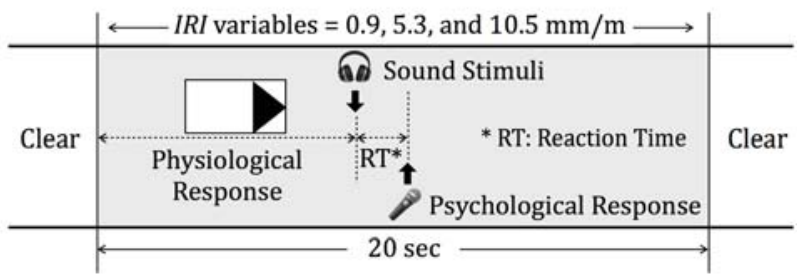

図-2＼cjkstart走行試験シナリオ

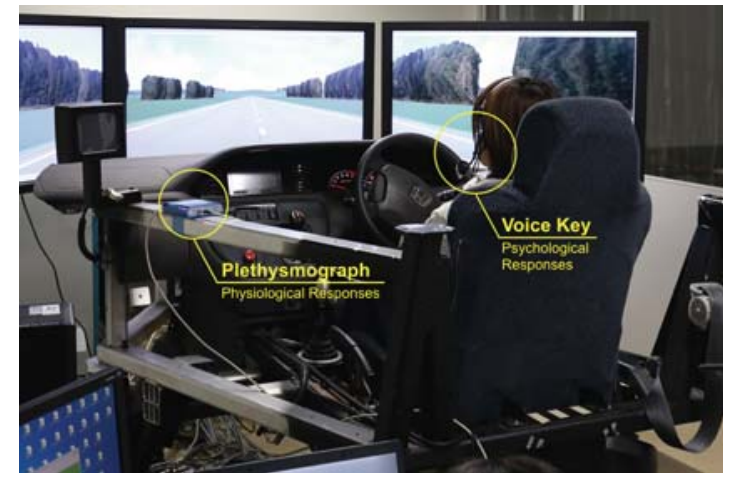

図-3ＤS による走行試験状況

および供用後の破損が生じた状態を想定し，IRI が(a) 0.9, (b) 5.3 および(c) $10.5 \mathrm{~mm} / \mathrm{m}$ の 3 水準とした. 走行試験に おける路面は，図-1 に示すプロファイルを用い，後述の 心理刺激提示前後の平均 IRI が所要の值となるよう設定 した. 走行条件は, 運転操作による生理・心理的負荷の影 響を排除するため助手席状態とし，1 試行あたり，各被験 者に対しランダムに与えられた各路面水準について，幹 線道路を想定した走行速度 $60 \mathrm{~km} / \mathrm{h}$ で 20 秒間体験するよ う設定した。試行回数は，各路面条件を 15 回の計 45 回 である。走行試験シナリオおよび走行試験状況は 図-2 および図-3に示す通りであり，各試行において以下 の心理および生理反応を計測した。

\section{a）心理反応}

心理反応は, 各路面状況において, 音刺激弁別試験によ り計測した．音刺激弁別試験とは，走行開始から約 10 秒 後に適度に弁別が負荷となるよう高音・中音・低音と音程 の異なる音刺激を参加者に提示し, 刺激認知後直ちに与 えられた音程を発声により「できる限り速く正確に」回答 するよう指示することで, 刺激提示から回答までの反応 時間を計測するものである ${ }^{20)}$. なお, 反応時間の計測は,

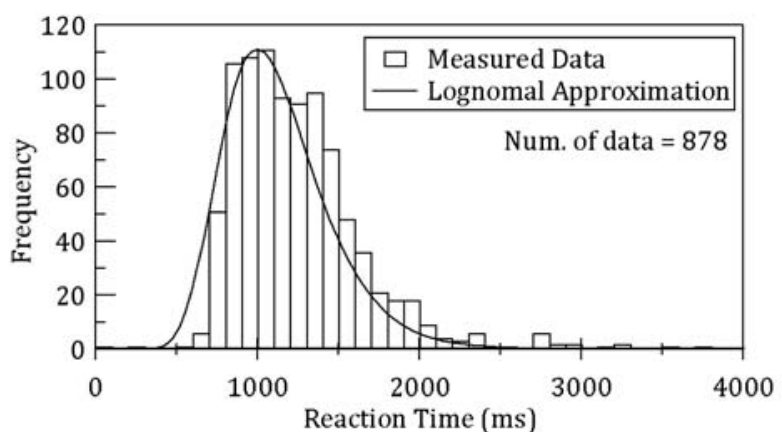

図-4 音程識別課題正答時の反応時間の頻度分布

ヘッドフォンによる音刺激の提示から回答までの反応時 間をミリ秒単位で記録可能な Voice Key を用いた。

b）生理反応

生理反応は，指尖脈波計測值の二階微分による脈波加 速度により得られた心拍変動データをもとに, HF および LF/HFにより計測した。 ここで，HF およびLF/HFは，生 理反応に及ぼす要因をラフネスに限定するため，上記の 心理反応計測に資する課題刺激提示直前までの值を用い た.

\section{（3）試験参加者}

走行試験には，参加者として，健常な男女 24 名（女性 12 名, 平均年齢 21.6 歳) の協力を得た. また, 本試験は, 北見工業大学「人を対象とする研究倫理審査委員会」の承 認を受け，全ての被験者から自由意志による試験参加へ の同意を得た上で実施した．なお，女性被験者 1 名につ いては，前述の心理および生理反応の計測エラーによる 久測のため, 以下の解析では 23 名から得られたデータを 解析対象とした.

\section{4.心理および生理反応の解析結果}

本章では，ラフネスが生理心理反応に及ぼす影響を明 らかにするため，DS による走行試験データに基づき，2 章で述べた各指標を用いた解析結果を示す。

\section{（1）心理反応}

\section{a）測定結果の概要とスクリーニング}

図-4 に全ての路面条件下における反応時間の頻度分布 を示す．なお，音程の判別が誤答となったものは，「でき る限り速く正確に」回答するという課題を正しく遂行で きていないため, 結果から除外している. 図-4 は, 得ら れた全 1035 点から，誤答であった 157 点 (15.2\%) を除 く 878 点のデータを示している. 図より，反応時間は対 数正規分布により近似できることがわかる. また, 平均值 より極端に長い反応時間が計測されている.これらの結 


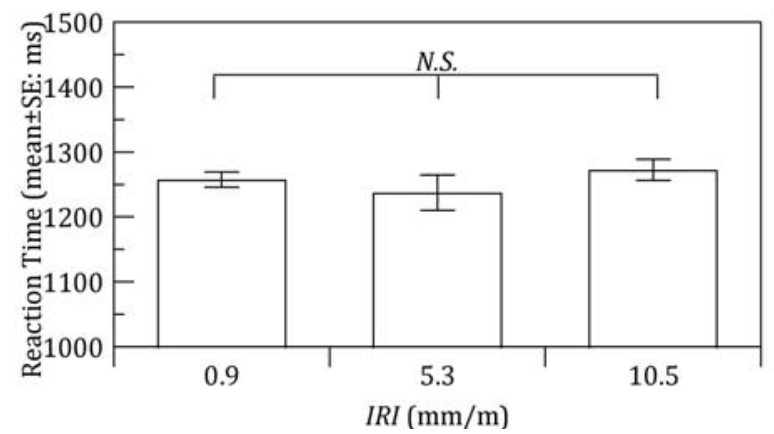

図-5 IRI ごとの平均反応時間

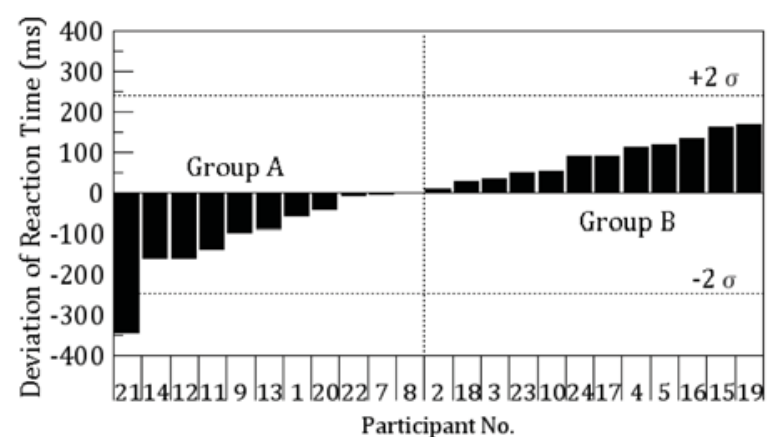

図-6 基淮路面 $(I R I=0.9 \mathrm{~mm} / \mathrm{m})$ との反応時間差

果も, 課題を正しく遂行できていないものと考えられる. そこで, 正答時の反応時間を対数変換し, 平均值から標準 偏差の3倍以上異なる值を外れ值として除外した. また, 本研究では, 路面条件の違いによる反応時間に着目して いるため，音程の違いは考慮せず，IRI 值ごとに各音程か ら得られた反応時間の平均值を用いて解析を行う.

\section{b) 反応時間と $I R I$ の関係}

図-5に IRI 毎の平均反応時間を示寸，図より，IRIが増 加するに従い，反応時間も増加する傾向にあるが，IRIを 独立変数とし反応時間を従属変数とした有意水準 $5 \%$ で の対応のある一元配置分散分析の結果, IRI の主効果に有 意差はみられず $(F(2,44)=0.78, p>0.05))$, 個人差で有意

$(F(22,44)=16.65, p<0.05))$ となった. ここで，反応時 間の絶対值の解釈は困難であるため, 図-6 に示寸通り, 被験者ごとに IRI が $0.9 \mathrm{~mm} / \mathrm{m}$ の路面より得られた結果を 基準とし，IRIが $5.3 \mathrm{~mm} / \mathrm{m}$ および $10.5 \mathrm{~mm} / \mathrm{m}$ における条 件下で得られた反応時間との相対的な差の平均值を求め 整理した．図中，参加者 6 は上述の通り欠測となってい る. 図より, 反応時間は, 基準路面上で得られた值に比べ, 減少する場合と増加する場合が同程度存在することがわ かった，そこで，本章では，図-6 に示す様に基淮路面か らの反応時間が減少したグループ A と増加したグループ B の参加者グループに分けて実施する. なお，参加者 21 は，解析対象とした全参加者の平均的な反応時間差に対 し，5\%有意水準の棄却域に相当する標準偏差の 2 倍以上 異なる結果となったことから，以降の解析では除外する

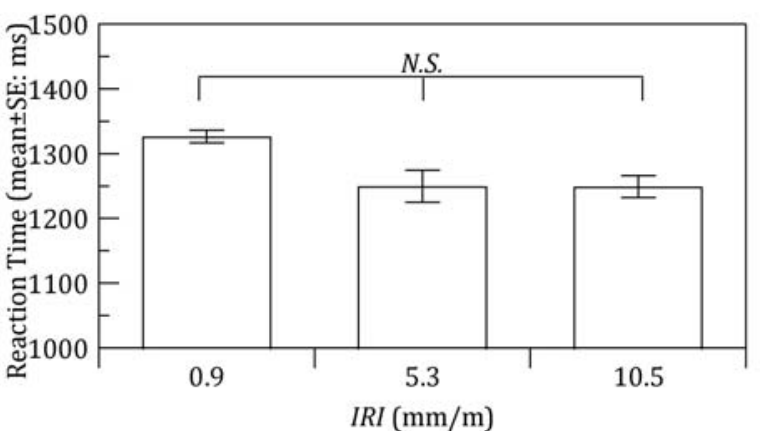

(a) グループ A : 基準路面に対し反応時間が減少する参加者群

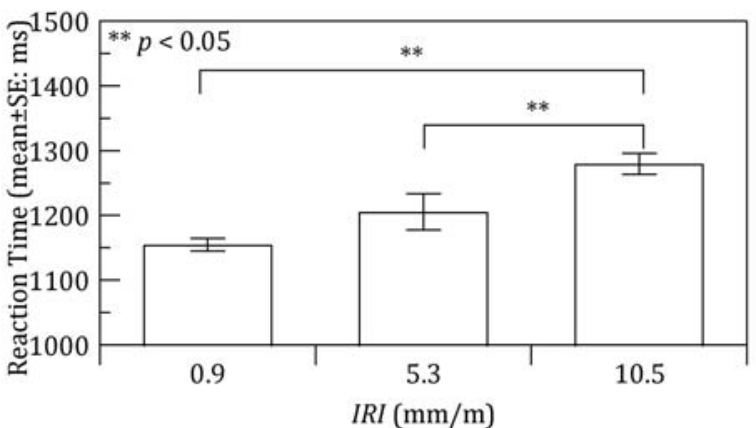

(b) グループ B : 基淮路面に対し反応時間が増加する参加者群

図-7 IRI と参加者グループ毎の平均反応時間の関係

こととした

c）参加者グループ別の反応時間解析

図-7 に，前項で判別したグループ毎の平均反応時間を 示す.また, 分散分析において, 主効果が有意となった場 合には, 事後にテューキーの HSD 法により多重比較検定 を行なった．図より，グループ A では，主効果に有意差 がみられなかった $(F(2,18)=2.97, p>0.05))$ 。一方，グル ープ B では，主効果に有意差があり $(F(2,22)=12.96, p<$ $0.05)$ ), 多重比較の結果, IRI が $0.9 \mathrm{~mm} / \mathrm{m}$ と $10.5 \mathrm{~mm} / \mathrm{m}$ お よび $5.3 \mathrm{~mm} / \mathrm{m}$ と $10.5 \mathrm{~mm} / \mathrm{m}$ の間で有意差がみられた. こ のことから, 反応時間が増加する参加者は, 運転行動が伴 わない場合であっても，ラフネスが注意資源に影響を及 ぼす結果となった。

\section{（2）生理反応}

生理反応の解析は, 前節で除外されたデータが得られ た試行時の結果を除き，反応時間との対応を取った上で 実施した．以下に心拍変動指標による生理反応の解析結 果を示す。

\section{a) $\mathrm{HF}$ と IRIの関係}

図-8に，参加者グループ毎のIRI と HF の関係を示す. ここで，HF は值が小さい程ストレスが高いことを表す。 図より, どちらのグループもIRI の増加に伴い HF が減少 しており, 精神的ストレスが増加する結果となった. また， 精神的ストレスの増加傾向は各グループで同様であるが, グループ B はグループ A に比べ，精神的ストレスが高い 


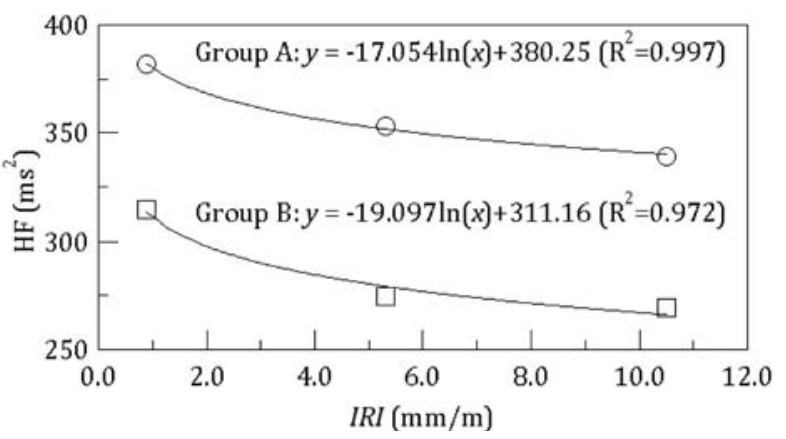

図-8ＩRI と心拍変動指標 $\mathrm{HF}$ の関係

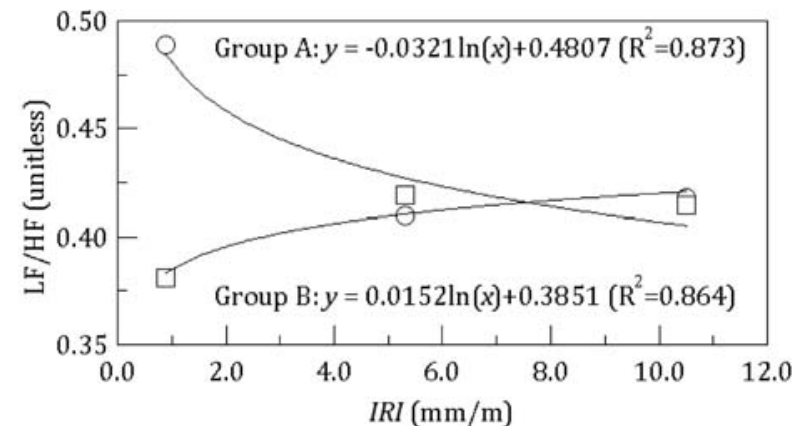

図-9 IRI と心拍変動指標 $\mathrm{LF} / \mathrm{HF}$ の関係

傾向にあった. 既往研究 ${ }^{21)}$ において, HF は乗り心地など の快適性に関わる，比較的短時間で生じる精神的ストレ スとの相関が報告されており，ここで得られた結果は整 合性のあるものである.

\section{b) LF/HF とIRIの関係}

図-9 に，参加者グループ毎の IRI と LF/HF の関係を示 す。ここで，LF/HF は值が大きい程ストレスが高いこと を表す. 図より, グループ A では, IRI の増加に伴い LF/HF が減少する一方, グループ B では, IRIの増加に伴いLF/HF が増加する結果となった。 ここで, 既往研究 ${ }^{21)}$ において,

LF/HF は, 時間変化に伴う精神的ストレスと相関し, 比 較的長い時間で生じる路面由来の精神的な疲労と関係す ることが示唆されている.この結果に鑑みると, グループ A は，試験時間内での疲労の発現がなく，一方のグルー プ B では, 疲労が発現したものといえる.このことから, グループ A とグループ B では, 生理反応の生じ方が異な るものといえる．車両振動刺激に対するヒトの感受性に は個人差があることが指摘されているが ${ }^{22)}$ ，本研究結果 は，既往研究成果を支持するものとなった.

\section{5. 生理心理反応に基づくラフネス評価}

前章では, ラフネスの指標である IRI と心理指標である 反応時間および生理指標である HF ならびに LF/HF の関 係について示した. 本章では, 上述の結果を俯瞰および統
表-1 IRIの増加に伴う各指標の反応

\begin{tabular}{cccc}
\hline 参加者 & 心理反応 & \multicolumn{3}{c}{ 生理反応 } \\
\cline { 2 - 4 } グループ & 反応時間 & $\mathrm{HF}$ & $\mathrm{LF} / \mathrm{HF}$ \\
\hline $\mathrm{A}$ & 減 少 & $\begin{array}{c}\text { 減 少 } \\
\text { (ストレス増加) }\end{array}$ & $\begin{array}{c}\text { 減 少 } \\
\text { (ストレス減少 })\end{array}$ \\
$\mathrm{B}$ & 増 加 & $\begin{array}{c}\text { 減 少 } \\
\text { (ストレス増加 })\end{array}$ & $\begin{array}{c}\text { 増 加 } \\
\text { (ストレス増加 })\end{array}$ \\
\hline
\end{tabular}

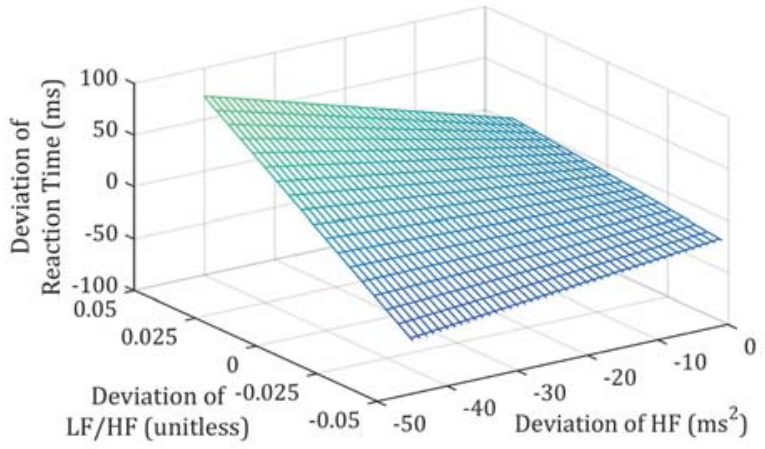

図-10 反応時間と心拍変動指標の関係

合し，ラフネスに対するヒトの反応に関するメカニズム を明らかにするとともに，IRIの許容限界について検討す る.

表-1 は走行試験より得られた結果を整理したものであ る. 表における HFより, 両参加者グループとも路面由来 の精神的ストレスを受けていることは明らかである．特 筆すべきは，参加者グループで異なる反応時間と LF/HF が同様の傾向を示しており，路面由来の精神疲労と認知 に関わる注意資源の間に関連性が示唆される点である. そこで，解析対象とした全参加者の反応時間と心拍変動 指標について，基準路面（IRI=0.9 $\mathrm{mm} / \mathrm{m} ）$ で得られた值 からの変化量を統合しモデル化したところ, 図-10に示す 結果が得られた. 図より，HF と LF/HF がともに精神的ス トレスを表す場合に反応時間が増加することが確認でき る.この結果は, ラフネスの増加が，ストレス増加に伴う 快適性の低下の夕ならず，疲労の増加に伴う安全性の低 下につながることを示している.

以上の結果に基づき，ヒトの認知に関わる注意資源の 観点から, 反応時間により IRI の許容限界を設定する必要 があるものと考えられる. 図-11 に，IRI とグループごと の各路面条件下での基準路面に対する反応時間差の平均 值の関係を示す。ここで，基準路面である $I R I=0.9 \mathrm{~mm} / \mathrm{m}$ における反応時間差は, 両グループとも $0 \mathrm{~ms}$ であるため, グラフのマーカーが重複している. 図中，IRI と反応時間 差の関係は二次関数により回帰した。 ここで，IRI = 0.9 $\mathrm{mm} / \mathrm{m}$ における反応時間の $95 \%$ 信頼区間の幅を求めたと ころ， $83.4 \mathrm{~ms}$ となった. 即ち，これ以上の反応時間の増 加は偶然には生じ得ないと考えられる. そこで, 図-11に 


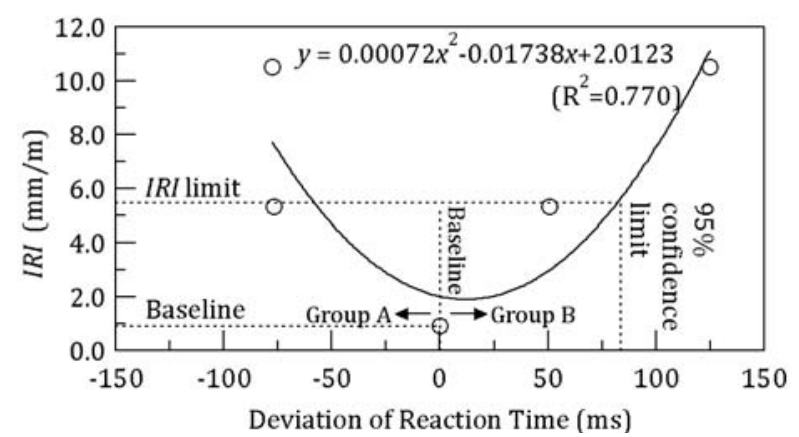

図-11 IRI と基準路面に対する反応時間差の関係

表-2 ラフネス評価に関する研究成果

\begin{tabular}{|c|c|}
\hline 物理指標 & 心理指標 \\
\hline $\begin{array}{l}\text { 藤田ら }{ }^{23)} \text { は, 市街地道路の } \\
\text { 路面モニタリングの結果, 一 } \\
\text { 般国道および主要地方道に } \\
\text { おける IRI は概ね } 5 \mathrm{~mm} / \mathrm{m} \text { 以 } \\
\text { 下であることを報告してい } \\
\text { る. }\end{array}$ & $\begin{array}{l}\text { 石田ら }{ }^{24)} \text { は, DS を用いた } \\
\text { 体感試験によるアンケート } \\
\text { 評価の結果, IRIが } 5 \mathrm{~mm} / \mathrm{m} \text { の } \\
\text { 場合, 走行速度 } 60 \mathrm{~km} / \mathrm{h} \text { では, } \\
\text { 乗り心地が「悪」く安心感と } \\
\text { して「やや倹」であること } \\
\text { を示している. }\end{array}$ \\
\hline 生理指標 & 本研究 \\
\hline $\begin{array}{l}\text { 富山ら }{ }^{21)} \text { は, DS を用いた } \\
\text { 体感試験の結果, 路面由来の } \\
\text { 精神疲労の観点から, 幹線道 } \\
\text { 路におちける IRI の許容水準と } \\
\text { して } 5.2 \mathrm{~mm} / \mathrm{m} \text { が目安となる } \\
\text { ことを示している. }\end{array}$ & $\begin{array}{l}\text { 本研究では, 路面とヒトの } \\
\text { 認知に関わる心理反応およ } \\
\text { び精神的ストレスに関わる } \\
\text { 生理反応を統合し検討した } \\
\text { ところ, IRIの許容限界が } 5.4 \\
\mathrm{~mm} / \mathrm{m} \text { となることを明らかに } \\
\text { した. }\end{array}$ \\
\hline
\end{tabular}

示す回帰式から, 反応時間差 $83.4 \mathrm{~ms}$ に対応する IRI を求 めたところ, IRI= $5.4 \mathrm{~mm} / \mathrm{m}$ となり, この值が，乗員の安 全性および快適性を考慮した幹線道路における IRI の許 容限界の目安になるものといえる.

なお，表-2 は，物理・心理・生理指標によるラフネス 評価の既往研究成果を整理したものであるが，いずれの 研究においても，概ね $I R I=5 \mathrm{~mm} / \mathrm{m}$ 程度が閾值となって おり, 本研究結果は, IRIの許容限界として妥当なもので あり,また，既往研究成果を裏付けるものとなった。

\section{6. おわりに}

ラフネスの評価は, 路面の物理特性とヒトの生理や心 理に関する情報の定量的な把握が必要であるため，非常 に複雑である. 本研究は, 路面の物理的な特性と, ヒトの 認知処理に関わる心理反応および精神的ストレスに関わ る生理反応との関係から, ラフネスに対するヒトの反応 メカニズムおよび許容限界について検討した. 以下に, 本 研究で得られた知見を示す.

(1) 心理反応に基づくラフネス評価の結果, 試験参加者 は, IRIの増加に伴いヒトの認知に関わる反応時間が
減少するグループ A と増加するグループ B に判別で きる. 特に後者は, IRIの増加に伴い反応時間が有意 に増加し，ラフネスが乗員の快適性のみならず安全 性にも影響を及ぼすことが示唆された.

（2）生理反応に基づくラフネス評価の結果，心拍変動指 標である HF は，両参加者グループとも，IRI の増加 に伴い減少する結果となり，ラフネスに対する精神 的ストレスを示した。 これは，HFが快適性に関わる 比較的短時間で生じる精神的ストレスと相関するた めである．一方， LF/HF は，IRI 増加に対し参加者グ ループ A ではストレス傾向を示さず，グループ B で はストレス傾向を示した. これは, LF/HF が比較的長 い時間で生じる精神的な疲労と関係するため，車両 振動刺激に対する振動感受性により差が生じたもの といえる.

（3）反応時間と心拍変動指標を統合し，ラフネスに対す る生理心理反応について検討したところ，反応時間 と LF/HF が同様の傾向を示し，路面由来の精神疲労 と認知に関わる注意資源の間に関連性が示唆された. この結果は, ラフネスの増加が, 精神的ストレスの増 加に伴う快適性の低下のみならず，疲労の増加に伴 う安全性の低下につながることを示している.

（4）ヒトの生理心理反応に基づき，ラフネスの許容限界 について検討したところ，幹線道路における快適性 および安全性を考慮した值として, IRI $=5.4 \mathrm{~mm} / \mathrm{m}$ が 得られた.この結果は, 物理・心理・生理指標に基づ く既往のラフネス評価結果と整合し，またそれらを 裏付けるものである.

以上の通り，路面評価においてヒトの生理心理計測は 非常に重要な役割を果たし，既存の評価手法に対しても 合理的な解釈を与えるものである. 近年, 社会基盤の老朽 化が急速に進行する中, 本研究成果は, 質の高い道路交通 環境整備に寄与するものと期待できる.

\section{謝辞}

本研究は，JSPS 科研費（若手研究（B）15K20843 およ び基盤研究（B）26289167）の助成を受けたものである. ここに記して感謝の意を表する.

\section{参考文献}

1) 日本道路協会 : 舖装の性能評価法 -必須および主要な性能 評価指標編-，丸善， 2006.

2) Haas, R., and Hudson, W.R.著 北海道土木技術会舗装研究委 員会訳 : 最新舗装マネジメント, 北海道土木技術会舗装研 究委員会, 2000.

3) Sayers, M.W.: On the Calculation of IRI from Longitudinal Road Profile, Journal of the Transportation Research Record, No.1501, pp.1-12, 1995. 
4) ISO: Mechanical vibration - Road surface profiles - Reporting of measured data, ISO8608: 1995, 1995.

5) Ishida, T., Kawamura, A., and Tomiyama, K.: Quantitative Evaluation of Ride Comfort Using a Driving Simulator, Proceedings of Transportation Research Board, Vol. 87, No.083090 (CD-ROM), 2008.

6) Janoff, M.S., Nick, J.B., Davit, B.S., and Hayhoe, G.F.: Pavement Roughness and Rideability, National Cooperative Highway Research Program Report 275, 1985.

7) Chou, C.P., and Wu, C.L.: Evaluation of Panel Characteristics and User-Based Pavement Serviceability, Transportation Research Record, No.1592, pp.98-106, 1997.

8) 石田 樹, 川村 彰, Alimujiang Yiming, 富山和也 : 生体信号 による舗装路面の乗り心地評価に関する基礎的研究, 土木 学会舗装工学論文集, 第 12 巻, pp.197-204, 2007.

9）郭 慶煥，磯崎大輔，姫野賢治 : 脳波による舗装路面の快適 性評価, 土木学会舗装工学論文集, 第 15 巻, pp.49-56, 2010.

10) ISO: Mechanical vibration and shock - Evaluation of Human Exposure to Whole-body Vibration - Part1: General Requirements, ISO2631-1:1985, 1985.

11) ISO: Mechanical vibration and shock - Evaluation of Human Exposure to Whole-body Vibration - Part1: General Requirements, ISO2631-1:1997, 1997.

12) 日本認知心理学会編 : 認知心理学ハンドブック, 有斐閣, 2013.

13) Task Force of the European Society of Cardiology and the North American Society of Pacing and Electrophysiology: Heart Rate Variability: Standards of measurement, physio-logical interpretation, and clinical use, European Heart Journal, Vol. 17, No. 3, pp. 354$381,1996$.

14）富山和也, 川村 彰, 石田 樹, 秋田谷勇輝: ドライビングシ ミュレータおよび生体情報を用いた路面乗り心地評価シス テムの構築, 土木学会論文集 F3 (土木情報学), Vol.68, No.2,
pp.I_135-I_141, 2012 .

15）国土交通省道路局：舗装点検要領，2016,

16）牧下 寛, 松永勝也: 心理的負荷が運転中の反応時間に与え る影響, 人間工学, Vol.41, No.4, pp.228-236, 2005.

17) Andersen, G.J., Ni, R., Bian, Z., and Kang, J.: Limits of spatial attention in three-dimensional space and dual-task driving performance, Accident Analysis and Prevention, Vol.43, No.1, pp.381-390, 2011.

18) Rossi, R., Gastaldi, M., Biondi, F., and Mulatti, C.: Evaluating the Impact of Processing Spoken Words on Driving - Experiments with Driving Simulator, Transportation Research Record, No.2321, pp.66-72, 2012.

19）富山和也, 川村 彰, 高橋 清, 石田 樹: 生体情報を利用し た路面乗り心地に基づく舗装の健全度モニタリング，土木 学会論文集 F3 (土木情報学), Vol.67, No.2, pp.I_125-I_132, 2011.

20) Pashler, H.: Dual-task interference in simple tasks: data and theory. Psychological Bulletin, Vol.116, Issue 2, pp.220-244, 1994.

21）富山和也，川村彰，Riccardo Rossi， Massimiliano Gastaldi, Claudio Mulatti： 心拍変動解析に基づく精神疲労を考慮した 路面平坦性評価, 土木学会論文集 E1 (舗装工学), Vol.71, No.3, pp. I_1-I_8, 2015.

22) 石田 樹, 川村 彰, Alimujiang Yiming, 富山和也, 中辻 隆: 心拍数変動を用いた路面の乗り心地評価方法，土木学会舗 装工学論文集, 第 13 巻, pp.17-24, 2008.

23) 藤田 旬, 富山和也, Nueraihemaitijiang ABLIZ, 川村彰: 簡 易平坦性測定および GIS に基づく市街地道路の路面モニタ リング，土木学会論文集 F3 (土木情報学)，Vol.69，No.2， pp.I_90-I_97, 2013.

24）石田 樹, 岳本秀人, 川村 彰, 白川龍生: ドライビングシミ ユレータによる舗装路面の乗心地・安心感評価, 土木学会 舗 装工学論文集, 第9 巻, pp.49-56, 2004. 


\section{PHYSIOPSYCHOLOGICAL RESPONSE OF VEHICLE PASSENGERS \\ TO SURFACE ROUGHNESS AND THE ACCEPTABLE LIMIT}

\section{Kazuya TOMIYAMA, Akira KAWAMURA, Riccardo ROSSI, Massimiliano GASTALDI and Claudio MULATTI}

Since surface roughness induces mechanical vibration affecting vehicle passengers, it needs to be evaluated with considering human response to the physical characteristics of road profiles. This study employs the following two physiopsychological measures that are associated with surface roughness in terms of the International Roughness Index (IRI) to quantify the safety and comfort of vehicle passengers: one is perceptional reaction time that refers to psychological attentional resources for evaluating cognitive performance of humans, and heart rate variability indices that indicate mental stress corresponding to physiological changes in the autonomic nervous systems. As a result, both the long- and short- term mental stress expressed by the physiological indices increase when psychological reaction time increases significantly proportional to the increase of roughness. This result indicates that surface roughness affects not only the ride comfort but also reduction of the safety by increasing reaction time with increasing mental fatigue. This study also provides the acceptable limit of the IRI for highways as $5.4 \mathrm{~mm} / \mathrm{m}$, which supports traditional research results regarding roughness evaluation. 